\title{
Effect of Hyperglycemia and the Aldose Reductase Inhibitor Tolrestat on Sural Nerve Biochemistry and Morphometry in Advanced Diabetic Peripheral Polyneuropathy
}

\author{
Anders A.F. Sima \\ Douglas A. Greene \\ Morton B. Brown \\ Thomas C. Hohman \\ David Hicks \\ G. Jay Graepel \\ Wieslaw J. Bochenek \\ Mirza Beg \\ Boas Gonen \\ The Tolrestat Study Group*
}

\begin{abstract}
Tolrestat is a well tolerated nonhydantoin aldose reductase inhibitor that has been reported to improve nerve conduction in diabetic animals and humans. Its effects on nerve biochemistry and structure have not been studied in patients with diabetic neuropathy. Patients with advanced diabetic neuropathy treated with long-term open-label tolrestat were randomly assigned to continuation on drug treatment or to placebocontrolled drug withdrawal for 12 months. At the end of this period, sural nerve biopsies were obtained for measurement of glucose, sorbitol, and fructose content, and for detailed morphometric analysis. Tolrestat ameliorated the glucosemediated increase in sorbitol and fructose in sural

nerve tissue. No statistically significant differences in nerve morphometry emerged between the two groups; however, both treatment groups exhibited increased nerve-fiber regeneration and normalization of axo-glial dysjunction and segmental demyelination following long-term tolrestat treatment. These findings are similar to those previously reported in a placebo-controlled sequential nerve biopsy study with the aldose reductase inhibitor sorbinil. Thus tolrestat is a biochemically effective aldose reductase inhibitor in human diabetic nerve with potential therapeutic efficacy for diabetic neuropathy. Journal of Diabetes and Its Complications 7;3:157-169, 1993.)
\end{abstract}

Departments of Pathology, Internal Medicine, and Biostatistics and the Michigan Diabetes Research and Training Center at the Univeristy of Michigan, Ann Arbor, Michigan, and Wyeth-Ayerst Research, Radnor, Pennsylvania, USA

Reprint requests to be sent to Dr. Anders A. F. Sima, University of Michigan Medical Center, 1331 East Ann Street, Box 0580, Ann Arbor, MI 48109.

* Tolrestat Study Group: R. Bernstein, Greenbrae, CA; J. Comstock, Houston, TX; S. Dippe, Scottsdale, AZ; Y. Harati, Houston, TX; L. Olansky, Oklahoma City, OK; and N. Soler, Springfield, IL 


\section{INTRODUCTION}

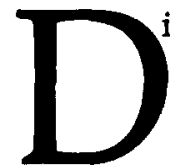
iabetic peripheral polyneuropathy is the most-frequent symptomatic chronic complication of diabetes mellitus and the most common cause of peripheral neuropathy in the Western World; ${ }^{1,2}$ yet its therapy remains essentially palliative. The underlying progressive loss, atrophy, and injury of nerve fibers ${ }^{3-7}$ are manifested by worsening objective distal symmetric sensory and motor deficits that predispose to foot ulceration and amputation. ${ }^{6,7}$ In contrast, positive dysesthetic or paresthetic symptoms ${ }^{5-8}$ have been associated with compensatory nerve fiber regeneration. ${ }^{5}$ Clinical and subclinical diabetic neuropathy ${ }^{8}$ correlate with the severity and duration of antecedent $t^{2,9,10}$ and coexisting hyperglycemia, ${ }^{611,12}$ implicating insulin deficiency, hyperglycemia, or both in the pathogenesis of the nerve damage. ${ }^{13}$

The metabolic pathways mediating the putative neurotoxic effects of insulin deficiency and hyperglycemia remain controversial. Increased nerve glucose levels, reflecting prevailing hyperglycemia, are believed to injure nerve fibers either directly or by damaging supporting endoneurial vascular or connective tissue. ${ }^{1,3,4,6,13,14}$ Two distinct, although not necessarily mutually exclusive, ${ }^{15}$ glucose-related metabolic pathways have been invoked in the pathogenesis of diabetic complications. One is nonenzymatic glycation of structural and functional proteins, and the other is increased activity of the polyol pathway involving the synthesis of excess sorbitol and fructose by aldose reductase and sorbitol dehydrogenase, respectively. ${ }^{1,3,4,6,16-18}$ The inferred ability of hyperglycemia to raise nerve glucose levels and stimulate these glucose-dependent biochemical pathways by mass action has not been rigorously examined in human nerve.

The most widely cited evidence implicating glucosemediated activation of the sorbitol pathway in nerve fiber damage is from a sequential nerve biopsy study with sorbinil, a potent but toxic hydantoin-based aldose reductase inhibitor (ARI). ${ }^{19}$ Sorbinil improved sural nerve biochemistry, function, and structure in a small group of patients with diabetic neuropathy. ${ }^{20,21}$ A robust increase in nerve fiber regeneration was associated with a reduction in nerve sorbitol content and a modest increase in nerve fiber density after 12 months of sorbinil treatment. ${ }^{20}$ Axo-glial dysjunction, ${ }^{21}$ an ultrastructural lesion of the node of Ranvier implicated in the slowing of nerve conduction in diabetic animals and patients, ${ }^{21,22}$ was normalized. These morphologic responses correlated with improvements in the action potential amplitude and conduction velocity of the sural nerve. ${ }^{20,21}$ These findings confirmed and partially explained earlier reports of improved nerve conduction in diabetic patients after sorbinil treatment. ${ }^{23}$ The pattern of response was similar to that evoked by a nonhydantoin-based aldose reductase inhibitor, statil, in diabetic BB rats. ${ }^{24}$

Recently, favorable electrophysiological responses in neuropathic diabetic patients have been observed with tolrestat, ${ }^{25}$ a well-tolerated, safe, and widely tested nonhydantoin-based ARI. ${ }^{26}$ However, the biochemical and morphological concomitants of these responses remained to be established. Therefore, sural nerve biopsies were obtained from patients with advanced diabetic polyneuropathy previously treated with tolrestat on a long-term open-label basis. These patients were randomly assigned in a double-blind fashion to either continued tolrestat or placebo treatment for an additional 12 months after which a single sural nerve biopsy was obtained from each patient for biochemical and morphometric analysis.

In the absence of nerve biopsies obtained prior to initiation of treatment, or a randomized parallel untreated control group, the morphometric data from the combined tolrestat-continued and tolrestat-withdrawn subjects were compared to a reference database of pretreatment sural nerve biopsies from the Sorbinil North American 12-month Neuropathy Trial ${ }^{4,20}$ and the Statil North American 18-month Neuropathy Trial, which had been analyzed in this laboratory. Because more-stringent exclusion criteria in these two latter ARI studies were designed to exclude the mostsevere cases of diabetic neuropathy, two statistical adjustments for age and duration of diabetes were used to minimize the morphometric imbalance in severity. However, residual differences in neuropathic damage probably remained even after statistical adjustment. Therefore, morphometric comparisons between tolrestat-treatment and reference patients emphasized characteristic short-term responses previously identified in ARI-treated patients, such as increased nerve fiber regeneration and normalization of axo-glial dysjunction, rather than a global morphometric assessment. The latter includes variables such as fiber density, which is likely to remain abnormal in advanced diabetic neuropathy despite effective ARI treatment.

\section{METHODS}

Study Design. Three hundred seventy-two patients with diabetic neuropathy who had elected open-label treatment after completing clinical trials with tolrestat were enrolled in a randomized, double-blind continuation/withdrawal study for 12 months. ${ }^{27}$ Sural nerve biopsies were obtained for biochemical and morphometric analysis from a small subgroup of these patients at six clinical centers. The patients who had been withdrawn from tolrestat for 12 months were considered to be untreated for purposes of measurement of the relatively labile intermediates of the aldose reductase pathway, glucose, sorbitol, and fructose. ${ }^{28}$ On the 
other hand, the more indelible morphometric effects of 3-4 years of tolrestat treatment might be expected to persist during a 12-month withdrawal period. Therefore, the tolrestat-continued and tolrestat-withdrawal patients were all considered to be tolrestattreated for the purpose of morphometric analysis. Morphometric parameters of all tolrestat-treated patients (drug continued and withdrawn patients) were compared with baseline sural nerve biopsies obtained from untreated neuropathic diabetic subjects entering two other ARI trials, despite the differences in entrance criteria. These comparisons were performed both before and after statistical adjustment for the covariates age and duration of diabetes.

Tolrestat Patient Population. Tolrestat-treated patients had been receiving 200 or $400 \mathrm{mg}$ of the drug daily for approximately 4 years on an open-label basis after having participated in earlier controlled clinical trials with tolrestat. At entry into the original trials, patients were required to have clinically stable insulindependent diabetes mellitus (IDDM) or non-insulindependent diabetes mellitus (NIDDM), and symptomatic diabetic peripheral sensorimotor polyneuropathy of unspecified duration and severity. Patients who had not been compliant with tolrestat administration, or had abnormal liver function tests (serum alanine amino transferase or aspartate amino transferase $>2 x$ upper limit of normal), abnormal renal function (serum creatinine $>2 \mathrm{mg} / \mathrm{dL}$ in men or $>1.6 \mathrm{mg} / \mathrm{dL}$ in women), unstable cardiovascular disease or neuropathy from causes other than diabetes, were excluded from the randomized withdrawal study. The remaining patients were stratified by their previous open-label tolrestat dose ( 200 or $400 \mathrm{mg} /$ day) and randomly assigned either to continued tolrestat or to placebo. Symptom assessment, neurological examinations, measurements of vibratory perception threshold, and nerve-conduction studies were performed at baseline and periodically thereafter during the 52 week study as previously described, ${ }^{25}$ and are reported in the accompanying paper. ${ }^{27}$ At the completion of the withdrawal study, subjects from both treatment groups at six participating centers were recruited into a supplementary biopsy protocol under a separate informed consent procedure.

Biopsy Procedure. Patients were instructed to omit taking the drug on the day of biopsy, designed to create a 23- to 33-h interval between the last medication and the biopsy procedure. Whole sural nerve biopsies $5-6 \mathrm{~cm}$ long were obtained surgically under local anesthesia through an incision proximal to the lateral malleolus on the patients' nondominant side. The biopsy specimen was immediately divided into four pieces of equal length. The two proximal segments were immediately placed in cacodylate-buffered $2.5 \%$ gluteralde- hyde (pH 7.4) and fixed for $48 \mathrm{~h}$ and postfixed in $1 \%$ osmium tetroxide ( $\mathrm{pH}$ 7.4). From one fixed specimen, cross and longitudinal sections were processed for electron microscopy, and from the other, individual nerve fibers were mechanically teased for lightmicroscopic analysis and categorized by scoring of fiber pathology as previously described. ${ }^{4}$ The two distal segments were immediately frozen in liquid nitrogen; one was subsequently processed for assessment of drug levels and the other for biochemical analysis. At the time of sural nerve biopsy blood samples were drawn for determination of plasma glucose levels, erythrocyte sorbitol concentrations, and plasma drug levels.

Biochemical Analysis and Measurement of Tolrestat Level. Carbohydrate and polyol levels in erythrocytes and sural nerve specimens were measured as their aldonitrile, the alditol acetate derivatives by capillary gas liquid chromatography using flame ionization detection. ${ }^{29}$ Nerve specimens were homogenized in distilled water, and erythrocytes were lysed by freezing and thawing in distilled water, following which $a$-methyl D-mannoside was added as an internal standard. The samples were deproteinized with $5 \%$ trichloroacetic acid, lyophilized, extracted with ether, derivatized with hydroxylamine hydrochloride, 4-(dimethylamino)pyridine and acetic anhydride, ${ }^{29}$ and injected into a HP-5890A chromatograph equipped with a SP-2100 fused silica capillary column. The measurements were calculated on the basis of an 8-point standard curve constructed by the addition of varying amounts of glucose, sorbitol, and fructose to samples of rat sciatic nerve or human erythrocytes; processing and analysis were identical to those used for the unknown samples. With this technique, the instrument response was linear for concentrations ranging from 6 to $230 \mathrm{nmol} / \mathrm{sample}$. Measurements in nerve samples were expressed as $\mathrm{nmol} / \mathrm{mg}$ protein, ${ }^{30}$ and measurements in erythrocytes were expressed as $\mathrm{nmol} / \mathrm{g}$ hemoglobin. ${ }^{31}$ Plasma glucose was measured by the glucose oxidase method on an Abbott bichromatic analyzer. Tissue and plasma levels of tolrestat were measured by high-performance liquid chromatography. ${ }^{32}$

Morphometric Analysis. Myelinated nerve fibers were examined by a combination of quantitative lightmicroscopic and electron-microscopic (EM) techniques previously described in detail. ${ }^{4,33}$ Automated, computer-driven light-microscopic morphometry of sural nerve cross sections was used to quantitate myelinated fiber density (the number of myelinated fibers per $\mathrm{mm}^{2}$ ), mean myelinated fiber size, and myelinated fiber occupancy (the percentage of total fascicular area occupied by myelinated fibers)..$^{33}$ Approximately 100 randomly selected individually teased myelinated nerve fibers were categorized into one of eight well-defined 
groupings by light-microscopic examination and expressed as percentages: (A) normal fibers ("\%normal"); or abnormal fibers exhibiting; (B) nodal swelling ("\%swelling"), (C) paranodal demyelination ("\%demyelinated"), (D) paranodal remyelination (so-called "intercalated internodes") ("\%intercalated"), (E) segmental demyelination ("\%segmental"), (F) excessive myelin wrinkling ("\%wrinkled"), (G) Wallerian degeneration ("\%Wallerian"), or $(\mathrm{H})$ remyelination/regeneration ("\%regenerated")., 433 \%ormal (category A) and attributes of fiber damage (categories B-G) were expressed as percentages of the total number of teased fibers counted minus the number of regenerated fibers so that the dilutional effect of regenerated fibers would not decrease the percentages of fibers in each of the other categories; ${ }^{20} \%$ regenerated was expressed as a percentage of the total number of nerve fibers. ${ }^{4,20}$ Electron microscopic morphometry quantitated axo-glial dysjunction, an ultrastructural lesion of the node of Ranvier characteristic of both human ${ }^{4,33}$ and animal ${ }^{22,34}$ diabetes. Axoglial dysjunction was defined as the loss of junctional complexes between terminal myelin loops and the axolemma that normally maintain the structural and functional integrity of the nodal apparatus. ${ }^{33,35}$ Axoglial dysjunction was expressed as the percentage of loops devoid of axoglial junctions ("\%axoglial"), and was calculated from a mean of 12.2 \pm 1.3 nodes of Ranvier per biopsy. All morphometric analyses were performed by examiners who were unaware of the identity of specimens.

Statistical Analysis. The Wilcoxon rank-sum test was used to compare biochemical data between the tolrestat-withdrawn and tolrestat-continued patients. Linear regression and the Pearson product-moment correlation were used to relate biochemical variables to sural nerve glucose for each treatment group. Equality of slopes was tested by a $t$ test.

Because the reference patients and the tolrestatcontinued/-withdrawn patients were derived from different population cohorts, putative effects of tolrestat treatment could not be distinguished from populationbased differences in nerve morphometry between the tolrestat-treated patients and the reference patients entering the sorbinil and statil trials. Therefore, in addition to direct comparisons of data from the tolrestat and reference groups, two methods of statistical adjustment were used. First, the morphometric data were adjusted for the currently accepted correlates of severity of nerve fiber damage in diabetes: age and duration of diabetes. ${ }^{4} Q$ Quadratic response surfaces including the terms "age," "(age)"," "duration," "(duration) $)^{2}$, and "age $\times$ duration" were fitted to the data for each morphometric variable. An analysis of covariance (ANCOVA) model was then used to compare the mean values of the tolrestat-continued/-withdrawn subjects to those of the reference subjects. These data were adjusted for the patients' ages and durations of diabetes (including their squares and product) that formed the quadratic surface as described above.

Second, a case-control adjustment was employed because quadratic surfaces need not be parallel when there is a significant treatment effect. For each tolrestat-treated patient from whom a biopsy was obtained, a "control" was selected from the reference patients. These pairs were matched for type of diabetes and, as closely as possible, for age and duration of diabetes as biopsy. The matching proceeded in a stepwise fashion with the closest remaining match identified at each step. The matching process ended when the remaining "control" and tolrestat-treated patients differed by more than 5 years for either age or duration of diabetes. By this criterion, seven matched IDDM pairs and ten matched NIDDM pairs were identified. Thus, only 17 of the 27 tolrestat-treated patients were successfully matched, and only these 17 pairs were considered in the case-control analysis. In general, the unmatched tolrestat patients were older or had a significantly longer duration of diabetes than the reference population.

The two-tailed Behrens-Fisher two-sample $t$ test, which does not assume equality of variances, was used to compare the tolrestat-treated and reference populations for both unadjusted and case-control adjusted data. Data are presented as mean $\pm \mathrm{SD}$.

\section{RESULTS}

Demographic and electrophysiologic parameters for the tolrestat-continued and tolrestat-withdrawn patients are presented in Table 1 . There were no statistically significant differences between these groups in any of these characteristics or in glycated hemoglobin levels at the time of biopsy. Nerve conduction attributes prior to initiation of tolrestat treatment, however, tended to be somewhat more abnormal in patients subsequently randomized to continuation of tolrestat, although these differences did not reach statistical significance.

\section{Comparison of Nerve Biochemistry in Tolrestat-Con-} tinued and Tolrestat-Withdrawn Patients. Tolrestat was detectable in sural nerve biopsies from all tolrestat-continued patients, whether treated with the 200 or $400 \mathrm{mg} /$ day dose, and was undetectable in biopsies from the tolrestat-withdrawn patients (Table 2). A review of patient records revealed that one tolrestatcontinued patient (No. 13; Figure 1) inadvertently took tolrestat on the morning of biopsy, whereas a second patient (No. 12; Figure 1) mistakenly discontinued tol- 
TABLE 1. DEMOGRAPHIC AND BASELINE ELECTROPHYSIOLOGICAL CHARACTERISTICS OF TOLRESTAT-TREATED AND REFERENCE SUBJECTS

\begin{tabular}{llclcc}
\hline & $\boldsymbol{n}$ & $\begin{array}{c}\text { Tolrestat } \\
\text { Continued }\end{array}$ & $\boldsymbol{n}$ & $\begin{array}{c}\text { Tolrestat } \\
\text { Withdrawn }\end{array}$ & $\begin{array}{c}\text { Reference } \\
\boldsymbol{n}=\mathbf{6 2}\end{array}$ \\
\hline Age (yr) & 13 & $56.5 \pm 12.9$ & 14 & $54.3 \pm 10.2$ & $51.3 \pm 11.0$ \\
Gender (M/F) & $10 / 3$ & & $11 / 3$ & & $11.1 \pm 7.2$ \\
Duration of diabetes (yr) & 12 & $18.6 \pm 12.0$ & 13 & $18.4 \pm 10.4$ & \\
Duration of neuropathy & 13 & $6.5 \pm 2.2$ & 12 & $6.2 \pm 2.5$ & \\
Duration of tolrestat rx & 13 & $4.0 \pm 0.4$ & 14 & $4.0 \pm 0.7$ & \\
Glycohemoglobin $(\%)$ & 13 & $6.5 \pm 1.2$ & 14 & $6.7 \pm 1.0$ & \\
Diabetes (IDDM/NIDDM) & $7 / 6$ & & $8 / 6$ & & \\
& & & & & \\
Conduction Velocity & 13 & $44.7 \pm 4.9$ & 14 & $47.8 \pm 5.6$ & \\
Median nerve motor & 13 & $38.5 \pm 15.1$ & 14 & $45.5 \pm 14.4$ & \\
Median nerve sensory & 13 & $46.0 \pm 8.3$ & 14 & $48.4 \pm 6.2$ & \\
Ulnar nerve motor & 13 & $35.1 \pm 15.7$ & 14 & $41.7 \pm 16.5$ & \\
Ulnar nerve sensory & 13 & $30.7 \pm 7.7$ & 14 & $34.6 \pm 7.9$ & \\
Tibial nerve motor & 13 & $29.7 \pm 8.0$ & 14 & $33.8 \pm 8.0$ & \\
Peroneal nerve motor & 13 & $25.3 \pm 8.7$ & 14 & $28.6 \pm 8.1$ & \\
Sural nerve sensory & & & & & \\
& & & & & \\
Evoked Amplitude & 13 & $5.1 \pm 2.7$ & 14 & $7.1 \pm 2.6$ & \\
Median nerve motor $(\mathrm{mV})$ & 13 & $4.9 \pm 4.9$ & 14 & $7.0 \pm 4.4$ & \\
Median nerve sensory $(\mu \mathrm{V})$ & 13 & $4.8 \pm 2.9$ & 14 & $7.1 \pm 3.1$ & \\
Ulnar nerve motor $(\mathrm{mV})$ & 12 & $4.0 \pm 4.5$ & 14 & $5.3 \pm 5.6$ & \\
Ulnar nerve sensory $(\mu \mathrm{V})$ & 13 & $2.3 \pm 3.3$ & 14 & $2.9 \pm 3.4$ & \\
Tibial nerve motor $(\mathrm{mV})$ & 13 & $1.3 \pm 1.6$ & 14 & $2.2 \pm 2.1$ & \\
Peroneal nerve motor $(\mathrm{mV})$ & 11 & $2.9 \pm 2.9$ & 13 & $2.4 \pm 2.2$ & \\
Sural nerve sensory $(\mu \mathrm{V})$ & & & & & \\
\hline
\end{tabular}

Values are mean $\pm S D$.

IDDM, insulin-dependent diabetes mellitus; NIDDM, non-insulin-dependent diabetes mellitus.

restat therapy several days prior to biopsy. These errors resulted in corresponding high and low plasma and nerve drug levels (Figure 1). The biochemical data from these two patients were excluded from the statistical analysis. The erythrocyte sorbitol concentration 23-33 h after the last dose of study drug was significantly correlated with the plasma glucose level in the tolrestat-withdrawn group but not in the tolrestatcontinued group (Figure 2). As tolrestat has no effect on plasma glucose levels, ${ }^{26}$ the data were pooled and demonstrated a significant correlation $(p<0.001)$ between the plasma and nerve glucose concentration (Figure 3). Tolrestat-continued patients had significantly lower sural nerve levels of sorbitol and fructose (Table 2). Sural nerve sorbitol and fructose rose as a function of sural nerve glucose concentration in tolrestat-withdrawn patients, whereas these relationships were not evident to tolrestat-continued patients (Figures 4 and 5). Erythrocyte sorbitol concentration correlated with sural nerve sorbitol content in the tol-

TABLE 2. EFFECT OF TOLRESTAT WITHDRAWAL, CONTINUATION, AND DOSE ON THE CONCENTRATION OF TOLRESTAT AND POLYOL PATHWAY INTERMEDIATES IN SURAL NERVE BIOPSIES

\begin{tabular}{lccccc}
\hline $\begin{array}{c}\text { Tolrestat } \\
\text { Treatment } \\
\text { Group }\end{array}$ & $n$ & $\begin{array}{c}\text { Tolrestat } \\
\text { ng/mg } \\
\text { Wet Weight }\end{array}$ & $\begin{array}{c}\text { Glucose } \\
\text { nmol } / \mathbf{m g} \\
\text { Protein }\end{array}$ & $\begin{array}{c}\text { Sorbitol } \\
\text { nmol/mg } \\
\text { Protein }\end{array}$ & $\begin{array}{c}\text { Fructose } \\
\text { nmol/mg } \\
\text { Protein }\end{array}$ \\
\hline Withdrawn & 14 & Not detectable & $184 \pm 84$ & $2.15 \pm 1.41$ & $5.69 \pm 3.34$ \\
Continued $200 \mathrm{mg}$ & 2 & $0.82 \pm 0.28$ & $102 \pm 81$ & $0.77 \pm 0.24$ & $0.98 \pm 0.80$ \\
Continued 400 mg & 9 & $1.14 \pm 0.42$ & $130 \pm 53$ & $0.85 \pm 0.21$ & $2.08 \pm 0.93$ \\
$p$ value* & & - & 0.190 & 0.006 & 0.007 \\
\hline
\end{tabular}

Values are mean $\pm S D$.

* $p$ Value for "Withdrawn" vs. "Continued 400 mg." 

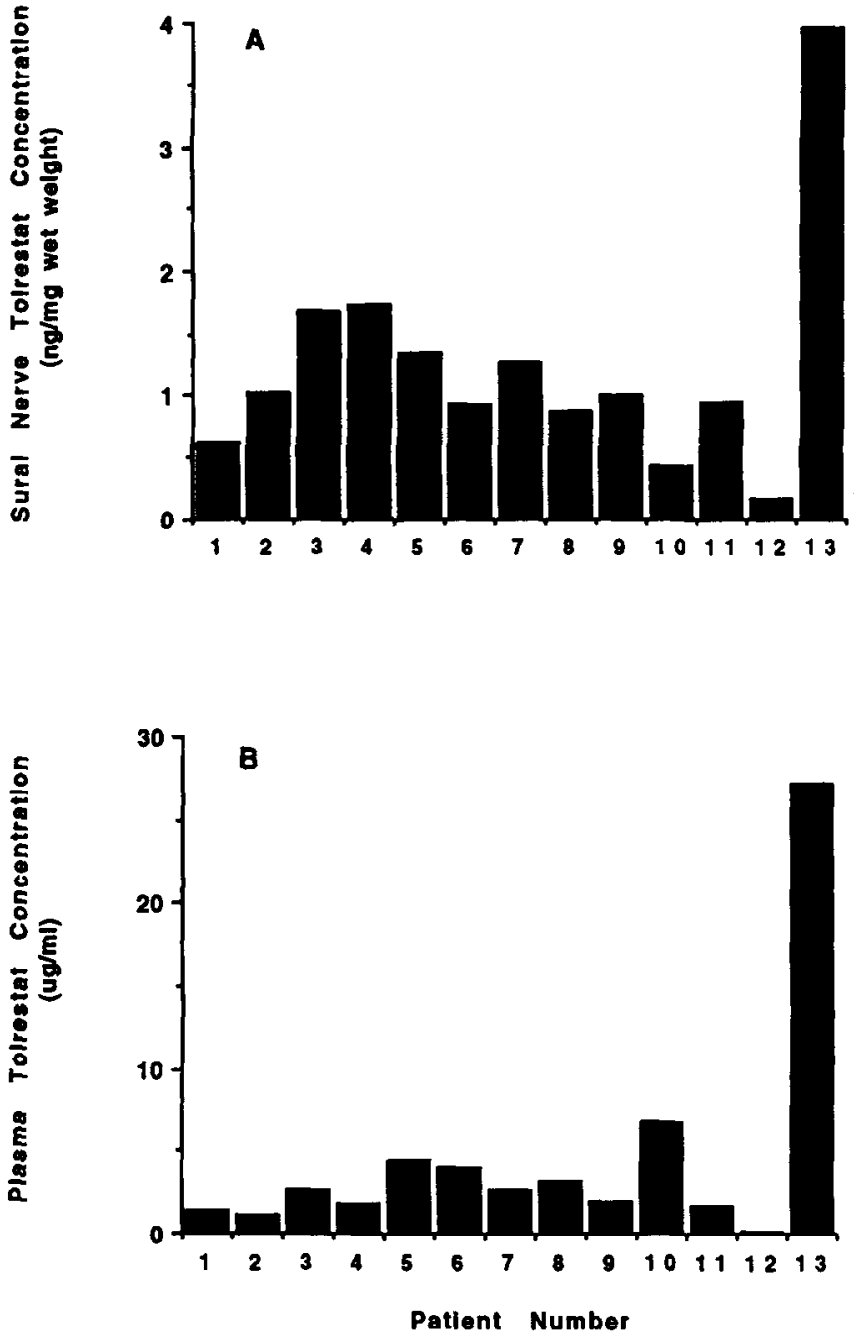

FIGURE 1. Sural nerve (A) and plasma (B) tolrestat concentrations at time of sural nerve biopsy in 13 subjects receiving long-term treatment with tolrestat. Subjects were to omit their tolrestat dose on the day of biopsy. Subject 12 had omitted drug for several days prior to biopsy, and subject 13 inadvertently took drug on the day of biopsy resulting in a higher plasma level. Subjects 1 and 2 were treated with $200 \mathrm{mg}$ tolrestat/day, and patients 3-13 with $400 \mathrm{mg}$ tolrestat/ day.

restat-continued and tolrestat-withdrawn patients in aggregate (Figure 6).

Nerve Morphometry. None of the morphometric parameters differed significantly between tolrestat-continued and tolrestat-withdrawn patients (data not shown). This result would be consistent with the previously described lack of detectable progression in nerve-fiber damage over 12 months in sural nerve biopsies from untreated neuropathic diabetic patients, ${ }^{20}$ or, theoretically, it could represent a plateauing of the effect of long-term tolrestat treatment.

Descriptive statistics for the demographic and morphometric parameters for the tolrestat-treated ("con- tinued" plus "withdrawn" patients) and reference populations are presented in Table 3 for all subjects and separately by type of diabetes. The results of the comparisons of the two groups by the three statistical methods (one unadjusted and two adjusted) are shown under the appropriate headings. The differences $(\Delta)$ between the unadjusted values for tolrestattreated patients and the reference patients, and the corresponding $p$ values are presented in the columns headed "unadjusted." The same comparisons based on the quadratic surface adjustment of the reference values are shown in the two columns headed "surface adjusted." Except for \%axoglial, the effects of the surface adjustment, defined as the simultaneous tests of the coefficients of the surface, were nonsignificant, i.e., the surfaces were not significantly different from zero (results not shown). The $p$ values for the coefficients of the surface for \%axaglial were $0.001,0.04$, and 0.0005 for all, NIDDM, and IDDM subjects, respectively (data not shown). The last two columns ("case control") present the differences between the values for the 17 tolrestat-treated patients (7 IDDM and 10 NIDDM) and their 17 case controls from the reference population, and the associated $p$ values.

As shown in the upper panel, the reference diabetic population was younger and had a shorter duration of diabetes than the tolrestat-treated patients. The most marked mismatch for duration was among the patients with IDDM: the tolrestat-treated and reference groups had durations of 26 and 14 years, respectively. As expected, however, the differences in age and disease duration between the case-control subgroups were insignificant.

Two of the more-characteristic morphological responses to ARI treatment in insulin-deficient diabetic patients and animals, an increase in \% regenerated (Figure 7) and a decrease in \%axoglial (Figure 8), ${ }^{20,24}$ were highly statistically significant for all tolrestat-treated patients and for tolrestat-treated IDDM patients before and after both methods of adjutment. \%Regenerated was also highly statistically significant for NIDDM patients and correlated in all patients with the duration of tolrestat treatment $(r=0.4, p=0.028)$ when the tolrestat-continued and tolrestat-withdrawn groups were combined. Fiber density, an approximation of the degree of fiber loss in diabetic neuropathy, was decreased in the tolrestat-treated patients compared to the reference population; however, the statistical significance of the difference in fiber density was greatly reduced in the IDDM subjects by the case-control analysis. \%Normal was unchanged overall, marginally increased in IDDM patients and marginally decreased in NIDDM patients treated with tolrestat. \%Demyelinated 


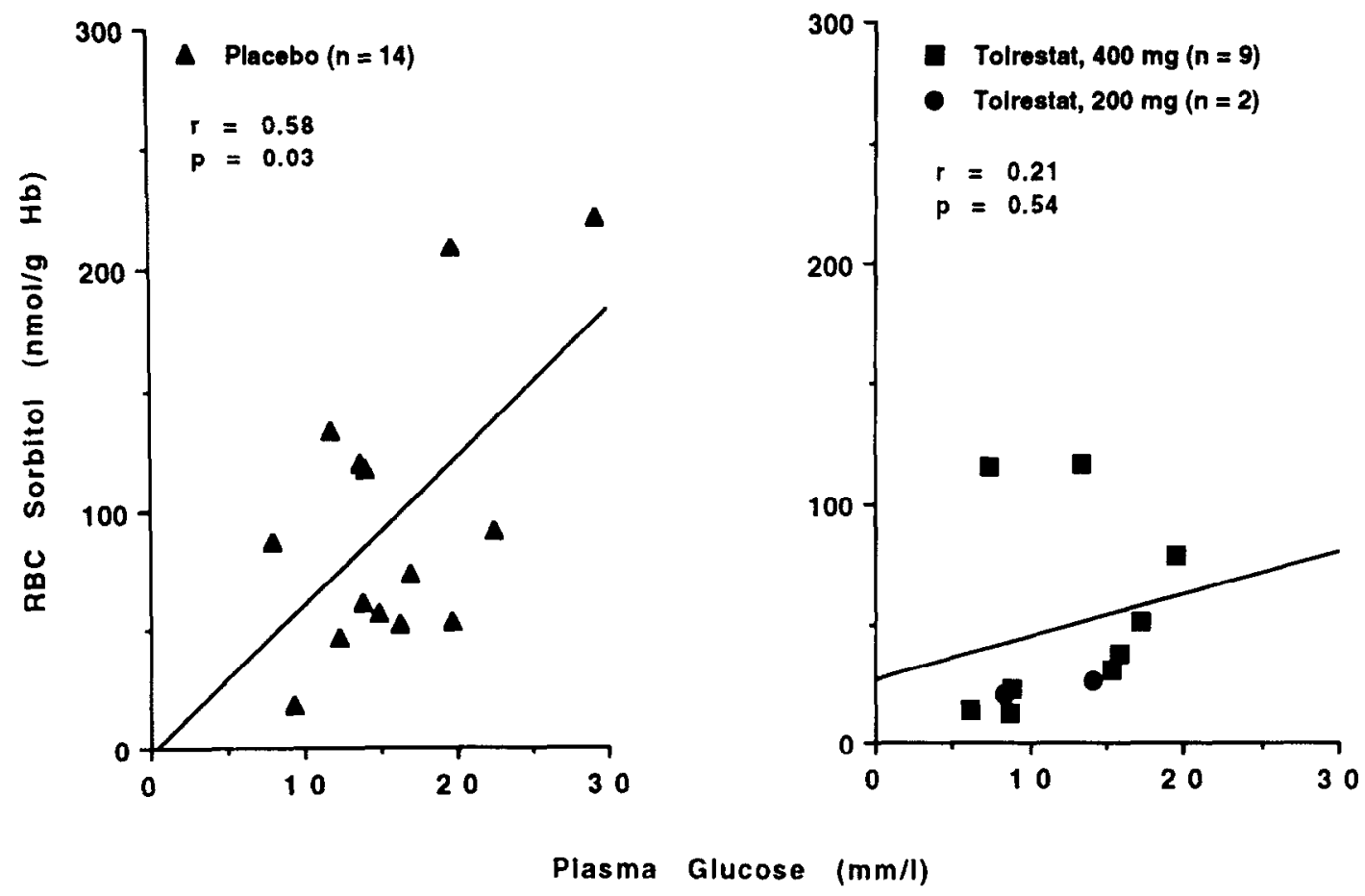

FIGURE 2. Relationship of erythrocyte (RBC) sorbitol content to plasma glucose concentration

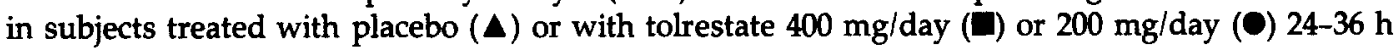
after the last dose.

decreased in IDDM patients, and \% intercalated increased overall and in IDDM patients treated with tolrestat, consistent with increased nodal remyelination in tolrestat-treated patients. \%Wrinkled appeared to show divergent effects, decreasing in IDDM and increasing in NIDDM patients with tolrestat treatment, whereas \%segmental (Figure 9) decreased consistently in all tolrestat-treated subgroups.

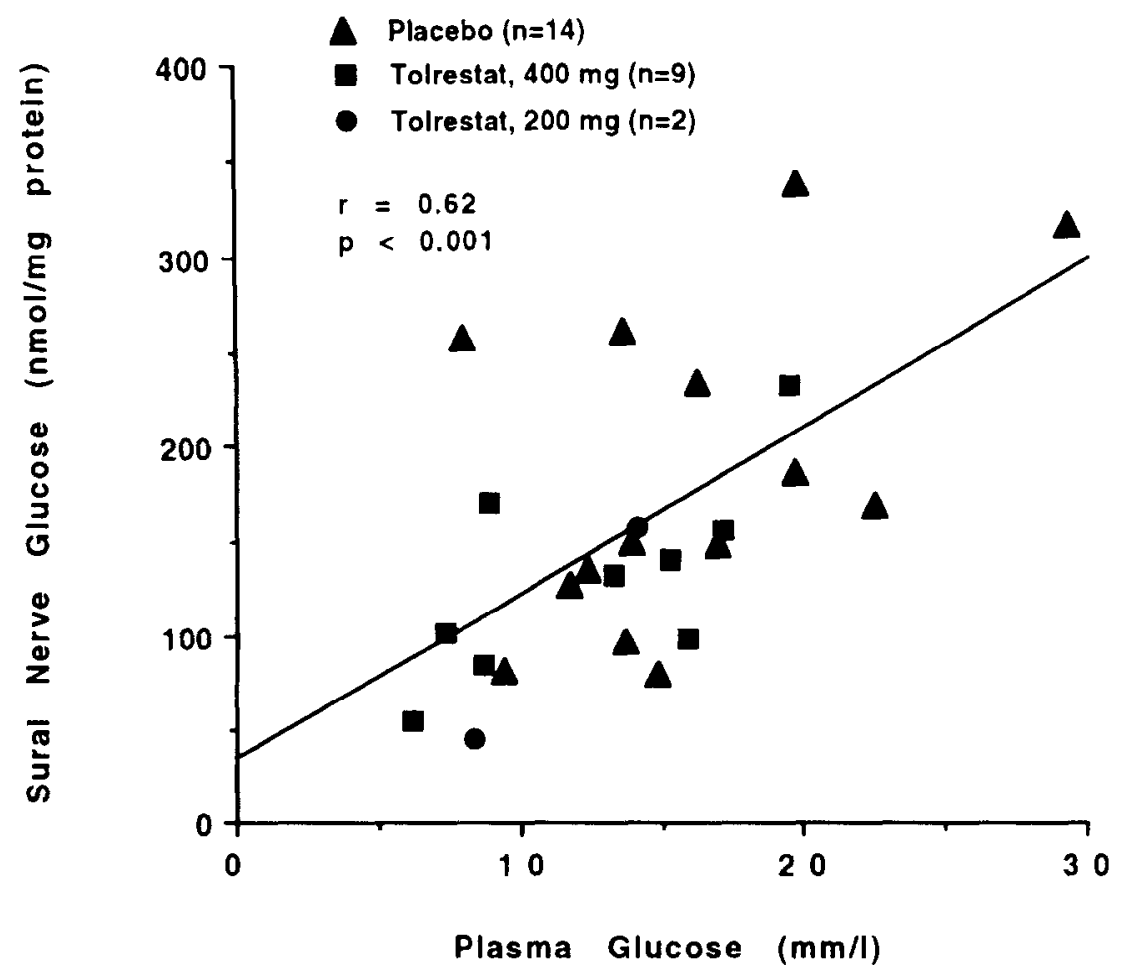

FIGURE 3. Relationship of sural nerve glucose content to plasma glucose at the time of biopsy in subjects receiving placebo $(\Delta)$, tolrestate $400 \mathrm{mg} /$ day $(\square)$, or 200 $\mathrm{mg} /$ day (O). 

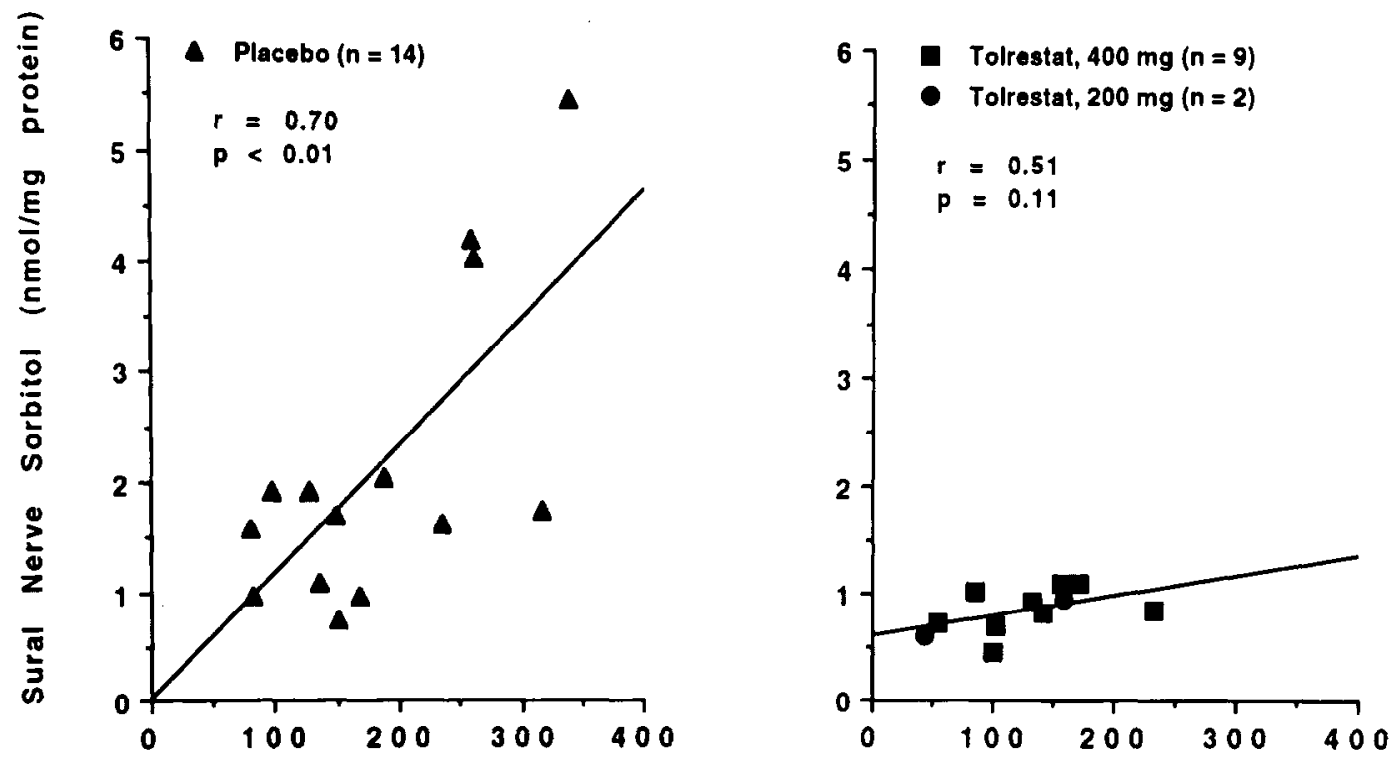

Sural Nerve Glucose' (nmol/mg protein)

FIGURE 4. Relationship of sural nerve sorbitol content to sural nerve glucose content in subjects receiving placebo ( $\Delta$ ), tolrestat $400 \mathrm{mg} /$ day ( $(\square)$, or $200 \mathrm{mg} /$ day (O).
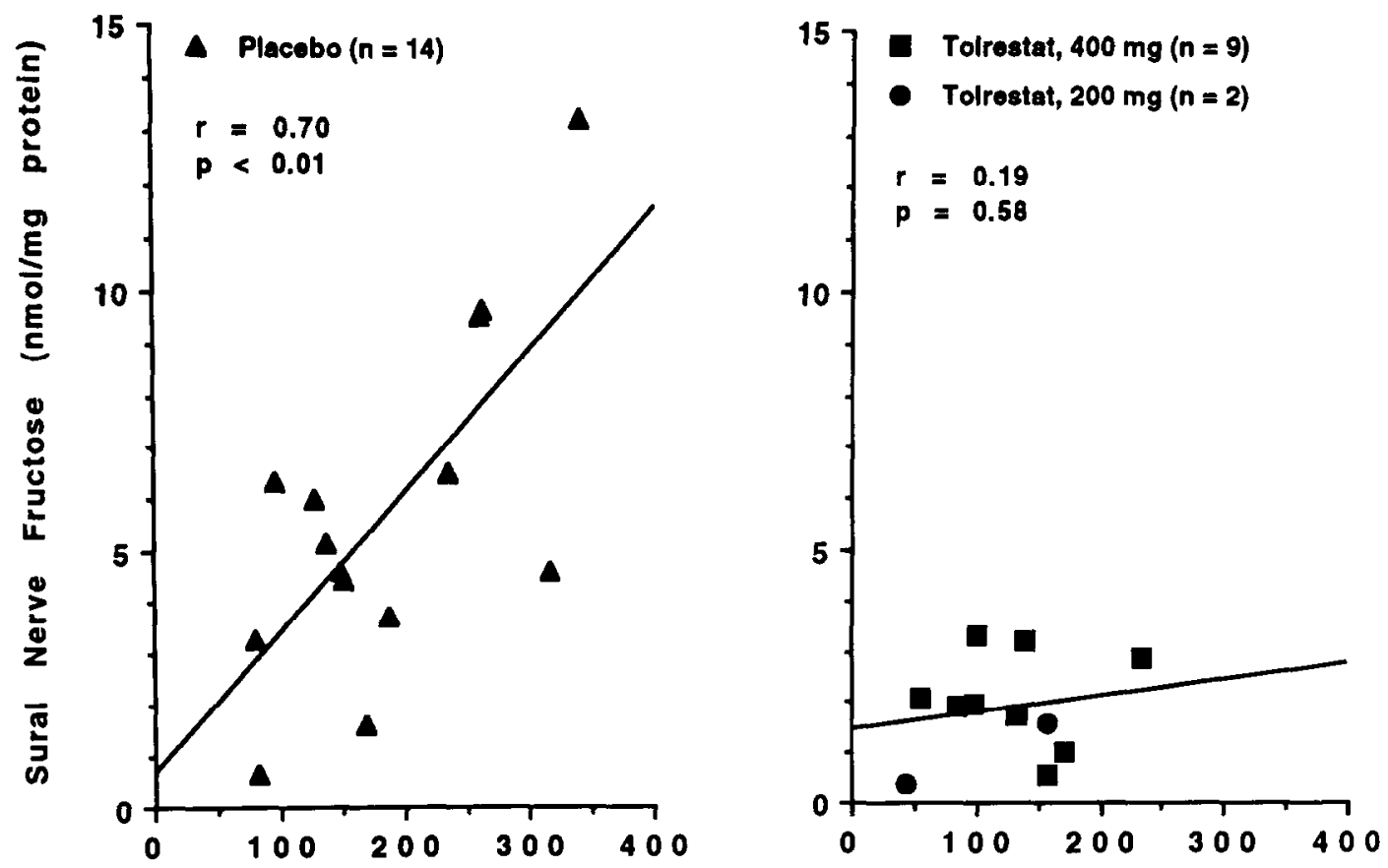

Sural Nerve Glucose (nmol/mg protein)

FIGURE 5. Relationship of sural nerve fructose content to sural nerve glucose content in subjects receiving placebo $(\Delta)$, tolrestat $400 \mathrm{mg} /$ day $(\square), 200 \mathrm{mg} /$ day $(\boldsymbol{\theta})$. 




FIGURE 6. Relationship of sural nerve sorbitol content to erythrocyte ( $R B C$ ) sorbitol content in subjects receiving placebo $(\Delta)$ or tolrestat $(400 \mathrm{mg} /$ day [D], or $200 \mathrm{mg} /$ day [0]) $24-$ $36 \mathrm{~h}$ after their last tolrestat dose.

\section{DISCUSSION}

Tolrestat has shown evidence of electrophysiological and clinical efficacy in the treatment of diabetic neuropathy in a long-term multicenter clinical trial, ${ }^{25,26}$ but the accompanying changes in biochemical and morphological parameters are unknown. Reduction in nerve sorbitol content, increased fiber regeneration and normalization of axoglial dysjunction have been observed in paired sural nerve biopsies after 12 months of treatment with the ARI sorbinil. ${ }^{20,21}$ These morphometric responses to sorbinil treatment have been associated with electrophysiological and clinical improvements in diabetic neuropathy. ${ }^{20,21}$ Sorbinil has, however, subsequently been withdrawn from clinical testing because of frequent idiosyncratic adverse reactions attributed to its hydantoin-like structure.

Single sural nerve biopsies from diabetic neuropathic patients treated with tolrestat exhibited similar morphometric effects of ARI treatment when compared to biopsies from patients withdrawn from tolrestat or from untreated reference populations, respectively. In these biopsies, sural nerve glucose content increased as a function of prevailing plasma glucose concentration at the time of biopsy independent of tolrestat treatment, suggesting that glucose equilibrates between the plasma and endoneurial compartments in human peripheral nerve. The glucose-related rises in sorbitol and fructose seen in tolrestat-with- drawn patients were largely prevented by tolrestat for up to 23-33 $\mathrm{h}$ after the last dose. This suggests a significant and prolonged inhibition of sural nerve aldose reductase by the drug. The reduction in nerve sorbitol content paralleled a reduction in erythrocyte sorbitol content. Because peripheral nerve poses a penetration barrier to tolrestat, but erythrocytes do not, these parallel effects of drug action can only be anticipated when the effective drug levels in the nerve are at steady state. ${ }^{36}$

Because pretreatment nerve biopsies were not obtained, statistical comparison with a reference database from other ARI trials was used to explore possible morphometric responses to tolrestat treatment. Evidence of ARI treatment effects, such as increased fiber regeneration ${ }^{20}$ and correction of axoglial dysjunction, ${ }^{21}$ were particularly sought. Two methods of statistical adjustment were performed in an attempt to counterbalance possible selection biases resulting from different entrance criteria among the studies, using age and duration of diabetes as surrogates for the severity of nerve-fiber damage. Because the simultaneous tests of the coefficients of the quadratic surface in age and diabetes duration were insignificant for all morphometric parameters except \%axoglial, it is unlikely that age and duration alone or in combination are the only determinants for severity of nerve-fiber damage. Thus neither method of adjustment would provide an entirely balanced comparison. Indeed, wherever large 
TABLE 3. DEMOGRAPHIC AND MORPHOMETRIC CHARACTERISTICS OF TOLRESTAT PATIENTS AND REFERENCE POPULATION

\begin{tabular}{|c|c|c|c|c|c|c|c|c|c|c|c|}
\hline \multirow{2}{*}{\multicolumn{2}{|c|}{$\begin{array}{c}\text { Variables }(+) \text { and }(-) \\
\text { Indicate Direction of } \\
\text { Anticipated Treatment } \\
\text { Effect }\end{array}$}} & \multirow[b]{2}{*}{$n$} & \multicolumn{3}{|c|}{ (mean $\pm S D)$} & \multicolumn{2}{|c|}{ Unadjusted } & \multicolumn{2}{|c|}{$\begin{array}{l}\text { Surface } \\
\text { Adjusted }\end{array}$} & \multicolumn{2}{|c|}{ Case Control } \\
\hline & & & $\begin{array}{l}\text { Tolrestat } \\
\text { Patients }\end{array}$ & $n$ & $\begin{array}{l}\text { Reference } \\
\text { Population }\end{array}$ & $\Delta$ & $p$ & $\Delta$ & $p$ & $\Delta$ & $p$ \\
\hline $\begin{array}{l}\text { Demographic } \\
\text { Age (yr) }\end{array}$ & $\begin{array}{l}\text { All } \\
\text { IDDM } \\
\text { NDDM }\end{array}$ & $\begin{array}{l}27 \\
15 \\
12\end{array}$ & $\begin{array}{l}56.3 \pm 11.4 \\
50.9 \pm 11.6 \\
63.0 \pm 7.1\end{array}$ & $\begin{array}{l}62 \\
23 \\
39\end{array}$ & $\begin{array}{l}51.4 \pm 11.5 \\
43.9 \pm 14.1 \\
55.8 \pm 6.6\end{array}$ & $\begin{array}{l}4.9 \\
7.2 \\
7.2\end{array}$ & $\begin{array}{l}0.07 \\
0.10 \\
0.006\end{array}$ & $\begin{array}{l}- \\
- \\
-\end{array}$ & $\begin{array}{l}- \\
-\end{array}$ & $\begin{array}{l}1.1 \\
0.0 \\
1.9\end{array}$ & $\begin{array}{l}\text { NS } \\
\text { NS } \\
\text { NS }\end{array}$ \\
\hline $\begin{array}{l}\text { Duration of } \\
\text { diabetes (yr) }\end{array}$ & $\begin{array}{l}\text { All } \\
\text { IDDM } \\
\text { NDDM }\end{array}$ & $\begin{array}{l}27 \\
15 \\
12\end{array}$ & $\begin{array}{l}20.1 \pm 10.9 \\
25.6 \pm 10.8 \\
13.3 \pm 6.5\end{array}$ & $\begin{array}{l}62 \\
23 \\
39\end{array}$ & $\begin{array}{l}11.6 \pm 7.5 \\
13.9 \pm 9.1 \\
10.2 \pm 6.2\end{array}$ & $\begin{array}{r}8.6 \\
11.7 \\
3.2\end{array}$ & $\begin{array}{l}0.0006 \\
0.002 \\
\text { NS }\end{array}$ & $\begin{array}{l}- \\
- \\
-\end{array}$ & $\begin{array}{l}- \\
-\end{array}$ & $\begin{array}{r}-0.4 \\
-1.1 \\
0.1\end{array}$ & $\begin{array}{l}\text { NS } \\
\text { NS } \\
\text { NS }\end{array}$ \\
\hline $\begin{array}{l}\text { Morphometric } \\
\text { \%Regenerated } \\
(+)\end{array}$ & $\begin{array}{l}\text { All } \\
\text { IDDM } \\
\text { NDDM }\end{array}$ & $\begin{array}{l}27 \\
15 \\
12\end{array}$ & $\begin{array}{l}32.2 \pm 11.2 \\
32.8 \pm 12.3 \\
31.4 \pm 10.1\end{array}$ & $\begin{array}{l}62 \\
23 \\
39\end{array}$ & $\begin{array}{l}6.8 \pm 4.0 \\
8.2 \pm 4.1 \\
6.0 \pm 3.7\end{array}$ & $\begin{array}{l}25.4 \\
24.6 \\
25.4\end{array}$ & $\begin{array}{l}0.0001 \\
0.0001 \\
0.0001\end{array}$ & $\begin{array}{l}22.6 \\
18.9 \\
26.3\end{array}$ & $\begin{array}{l}0.0001 \\
0.0001 \\
0.0001\end{array}$ & $\begin{array}{l}22.9 \\
19.6 \\
25.2\end{array}$ & $\begin{array}{l}0.0001 \\
0.003 \\
0.0001\end{array}$ \\
\hline $\begin{array}{l}\text { \%Axoglial } \\
(-)\end{array}$ & $\begin{array}{l}\text { All } \\
\text { IDDM } \\
\text { NDDM }\end{array}$ & $\begin{array}{r}24 \\
15 \\
9\end{array}$ & $\begin{array}{l}13.8 \pm 3.5 \\
12.3 \pm 3.1 \\
16.2 \pm 2.7\end{array}$ & $\begin{array}{l}62 \\
23 \\
39\end{array}$ & $\begin{array}{l}23.1 \pm 10.4 \\
33.8 \pm 7.5 \\
16.8 \pm 5.6\end{array}$ & $\begin{array}{r}-9.3 \\
-21.5 \\
-0.6\end{array}$ & $\begin{array}{c}0.0001 \\
0.0001 \\
\text { NS }\end{array}$ & $\begin{array}{r}-11.6 \\
-23.6 \\
-3.1\end{array}$ & $\begin{array}{l}0.0001 \\
0.0002 \\
0.08\end{array}$ & $\begin{array}{r}-10.8 \\
-20.7 \\
-3.6\end{array}$ & $\begin{array}{c}0.0004 \\
0.0001 \\
\text { NS }\end{array}$ \\
\hline $\begin{array}{l}\text { Fiber density } \\
\left(\text { no./mm }{ }^{2}\right) \\
(+)\end{array}$ & $\begin{array}{l}\text { All } \\
\text { IDDM } \\
\text { NDDM }\end{array}$ & $\begin{array}{l}27 \\
15 \\
12\end{array}$ & $\begin{array}{l}1786 \pm 1356 \\
1768 \pm 1324 \\
1809 \pm 1454\end{array}$ & $\begin{array}{l}62 \\
23 \\
39\end{array}$ & $\begin{array}{l}3226 \pm 1745 \\
3028 \pm 1645 \\
3344 \pm 1812\end{array}$ & $\begin{array}{l}-1440 \\
-1260 \\
-1535\end{array}$ & $\begin{array}{l}0.0001 \\
0.014 \\
0.006\end{array}$ & $\begin{array}{r}-1044 \\
-1237 \\
-907\end{array}$ & $\begin{array}{l}0.016 \\
0.06 \\
\text { NS }\end{array}$ & $\begin{array}{l}-1239 \\
-1021 \\
-1391\end{array}$ & $\begin{array}{c}0.06 \\
\text { NS } \\
\text { NS }\end{array}$ \\
\hline $\begin{array}{l}\text { \%Normal } \\
(+)\end{array}$ & $\begin{array}{l}\text { All } \\
\text { IDDM } \\
\text { NDDM }\end{array}$ & $\begin{array}{l}27 \\
15 \\
12\end{array}$ & $\begin{array}{l}44.2 \pm 16.9 \\
50.2 \pm 16.2 \\
36.6 \pm 15.2\end{array}$ & $\begin{array}{l}62 \\
23 \\
39\end{array}$ & $\begin{array}{l}43.5 \pm 11.5 \\
39.9 \pm 8.3 \\
45.5 \pm 12.7\end{array}$ & $\begin{array}{r}0.7 \\
10.3 \\
-8.9\end{array}$ & $\begin{array}{l}\text { NS } \\
0.04 \\
0.09\end{array}$ & $\begin{array}{r}1.0 \\
11.2 \\
-7.3\end{array}$ & $\begin{array}{c}\text { NS } \\
0.03 \\
\text { NS }\end{array}$ & $\begin{array}{r}-1.8 \\
6.3 \\
-7.5\end{array}$ & $\begin{array}{l}\text { NS } \\
\text { NS } \\
\text { NS }\end{array}$ \\
\hline $\begin{array}{l}\text { \%Swelling } \\
(-)\end{array}$ & $\begin{array}{l}\text { All } \\
\text { IDDM } \\
\text { NDDM }\end{array}$ & $\begin{array}{l}27 \\
15 \\
12\end{array}$ & $\begin{array}{l}4.2 \pm 3.9 \\
4.8 \pm 4.4 \\
3.4 \pm 3.2\end{array}$ & $\begin{array}{l}62 \\
23 \\
39\end{array}$ & $\begin{array}{l}4.6 \pm 3.2 \\
5.9 \pm 4.3 \\
3.8 \pm 2.0\end{array}$ & $\begin{array}{l}-0.4 \\
-1.1 \\
-0.4\end{array}$ & $\begin{array}{l}\text { NS } \\
\text { NS } \\
\text { NS }\end{array}$ & $\begin{array}{l}-1.0 \\
-1.8 \\
-0.7\end{array}$ & $\begin{array}{l}\text { NS } \\
\text { NS } \\
\text { NS }\end{array}$ & $\begin{array}{r}-1.0 \\
-2.9 \\
0.3\end{array}$ & $\begin{array}{l}\text { NS } \\
\text { NS } \\
\text { NS }\end{array}$ \\
\hline $\begin{array}{l}\text { \%Demyelinated } \\
(-)\end{array}$ & $\begin{array}{l}\text { All } \\
\text { IDDM } \\
\text { NDDM }\end{array}$ & $\begin{array}{l}27 \\
15 \\
12\end{array}$ & $\begin{aligned} 11.6 & \pm 10.6 \\
9.6 & \pm 5.0 \\
14.2 & \pm 14.8\end{aligned}$ & $\begin{array}{l}62 \\
23 \\
39\end{array}$ & $\begin{array}{l}11.5 \pm 4.3 \\
13.2 \pm 3.5 \\
10.5 \pm 4.4\end{array}$ & $\begin{array}{r}0.1 \\
-3.6 \\
3.7\end{array}$ & $\begin{array}{c}\text { NS } \\
0.024 \\
\text { NS }\end{array}$ & $\begin{array}{r}-0.5 \\
-5.2 \\
2.7\end{array}$ & $\begin{array}{c}\text { NS } \\
0.003 \\
\text { NS }\end{array}$ & $\begin{array}{r}0.5 \\
-5.9 \\
4.9\end{array}$ & $\begin{array}{c}\text { NS } \\
0.01 \\
\text { NS }\end{array}$ \\
\hline $\begin{array}{l}\text { \%Wrinkled } \\
(-)\end{array}$ & $\begin{array}{l}\text { All } \\
\text { IDDM } \\
\text { NDDM }\end{array}$ & $\begin{array}{l}27 \\
15 \\
12\end{array}$ & $\begin{array}{l}23.8 \pm 13.3 \\
18.2 \pm 14.1 \\
30.8 \pm 8.2\end{array}$ & $\begin{array}{l}62 \\
23 \\
39\end{array}$ & $\begin{array}{l}24.2 \pm 7.3 \\
27.3 \pm 5.5 \\
22.4 \pm 7.7\end{array}$ & $\begin{array}{r}-0.4 \\
-9.1 \\
8.4\end{array}$ & $\begin{array}{l}\text { NS } \\
0.03 \\
0.006\end{array}$ & $\begin{array}{r}1.1 \\
-8.8 \\
9.1\end{array}$ & $\begin{array}{l}\text { NS } \\
0.03 \\
0.005\end{array}$ & $\begin{array}{r}3.5 \\
-1.6 \\
7.0\end{array}$ & $\begin{array}{l}\text { NS } \\
\text { NS } \\
0.06\end{array}$ \\
\hline $\begin{array}{l}\text { \%Intercalated } \\
(+)\end{array}$ & $\begin{array}{l}\text { All } \\
\text { IDDM } \\
\text { NDDM }\end{array}$ & $\begin{array}{l}27 \\
15 \\
12\end{array}$ & $\begin{array}{l}12.6 \pm 6.3 \\
13.0 \pm 7.0 \\
12.0 \pm 5.6\end{array}$ & $\begin{array}{l}62 \\
23 \\
39\end{array}$ & $\begin{array}{l}8.2 \pm 5.1 \\
7.1 \pm 4.6 \\
8.9 \pm 5.2\end{array}$ & $\begin{array}{l}3.4 \\
5.9 \\
3.1\end{array}$ & $\begin{array}{c}0.003 \\
0.008 \\
\text { NS }\end{array}$ & $\begin{array}{l}3.4 \\
5.4 \\
2.3\end{array}$ & $\begin{array}{c}0.018 \\
0.015 \\
\text { NS }\end{array}$ & $\begin{array}{l}2.5 \\
4.0 \\
1.6\end{array}$ & $\begin{array}{l}\text { NS } \\
\text { NS } \\
\text { NS }\end{array}$ \\
\hline $\begin{array}{l}\text { \%Wallerian } \\
(-)\end{array}$ & $\begin{array}{l}\text { All } \\
\text { IDDM } \\
\text { NDDM }\end{array}$ & $\begin{array}{l}27 \\
15 \\
12\end{array}$ & $\begin{array}{l}3.4 \pm 3.9 \\
4.2 \pm 3.9 \\
2.4 \pm 3.9\end{array}$ & $\begin{array}{l}62 \\
23 \\
39\end{array}$ & $\begin{array}{l}4.0 \pm 2.9 \\
2.9 \pm 2.5 \\
4.7 \pm 2.9\end{array}$ & $\begin{array}{r}-0.6 \\
1.3 \\
-2.3\end{array}$ & $\begin{array}{l}\text { NS } \\
\text { NS } \\
0.08\end{array}$ & $\begin{array}{r}0.0 \\
2.4 \\
-1.6\end{array}$ & $\begin{array}{c}\text { NS } \\
0.07 \\
\text { NS }\end{array}$ & $\begin{array}{r}1.6 \\
3.3 \\
-1.7\end{array}$ & $\begin{array}{l}\text { NS } \\
\text { NS } \\
\text { NS }\end{array}$ \\
\hline $\begin{array}{l}\text { \%Segmental } \\
(-)\end{array}$ & $\begin{array}{l}\text { All } \\
\text { IDDM } \\
\text { NDDM }\end{array}$ & $\begin{array}{l}27 \\
15 \\
12\end{array}$ & $\begin{array}{c}0.3 \pm 1.1 \\
0 \\
0.7 \pm 1.7\end{array}$ & $\begin{array}{l}62 \\
23 \\
39\end{array}$ & $\begin{array}{l}4.1 \pm 3.3 \\
3.7 \pm 2.9 \\
4.2 \pm 3.6\end{array}$ & $\begin{array}{l}-3.8 \\
-3.7 \\
-3.5\end{array}$ & $\begin{array}{l}0.0001 \\
0.0001 \\
0.001\end{array}$ & $\begin{array}{l}-4.0 \\
-3.3 \\
-4.4\end{array}$ & $\begin{array}{l}0.001 \\
0.0002 \\
0.001\end{array}$ & $\begin{array}{l}-4.0 \\
-3.1 \\
-4.7\end{array}$ & $\begin{array}{l}0.0005 \\
0.03 \\
0.008\end{array}$ \\
\hline
\end{tabular}

differences existed between the tolrestat-treated and reference patients for the unadjusted data, similar directions of difference appeared in the adjusted data. However, the differences in the adjusted data were less statistically significant in many instances, in part because the case-control method used fewer subjects than the surface-adjusted or unadjusted methods. Nevertheless, striking morphometric differences appeared between tolrestat-treated and reference pa- tients, particularly in \%regenerated and \%axoglial, which paralleled the previously noted effects of sorbinil..$^{20,21}$

Nerve fiber regeneration was similarly increased when compared to the untreated reference population in both tolrestat-continued and tolrestat-withdrawn patients, and the degree of regeneration correlated with the duration of tolrestat treatment. Therefore, this may reflect a positive ARI treatment effect related to duration of therapy (and/or a positive effect of unin- 




FIGURE 7. Micrographs of cross-sectional sural nerves from a tolrestat-treated patient (a) and a nontreated case control patient (b). Note in (a) the increased number of thinly myelinated regenerated fibers often appearing in clusters (arrowheads). Magnification $\times 330$.

terrupted tolrestat administration up to the time of biopsy). The fact that nerve-fiber regeneration was increased in tolrestat-treated patients undergoing a single nerve biopsy indicates that this ARI treatment effect is not conditioned by a previous nerve biopsy, as has been suggested. ${ }^{8} \%$ Axoglial was reduced in tolrestat-treated patients to a level previously reported for nondiabetic control subjects, ${ }^{4}$ as reported earlier in patients treated with sorbinil. ${ }^{21}$ The absence of statistically significant differences in \%regenerated or \%axoglial between tolrestat-withdrawn and tolrestat-continued subjects suggests that once ARI treatment is stopped, the loss of regenerated fibers or reoccurrence of axoglial dysjunction is slow.

Apparent differences in fiber density between the tolrestat-treated patients and the reference population most likely reflect underlying imbalances between the tolrestat-treated and reference groups despite adjustment for age and diabetes duration. Fiber density, which varies widely in neuropathic patients entering ARI trials, would be expected to increase modestly

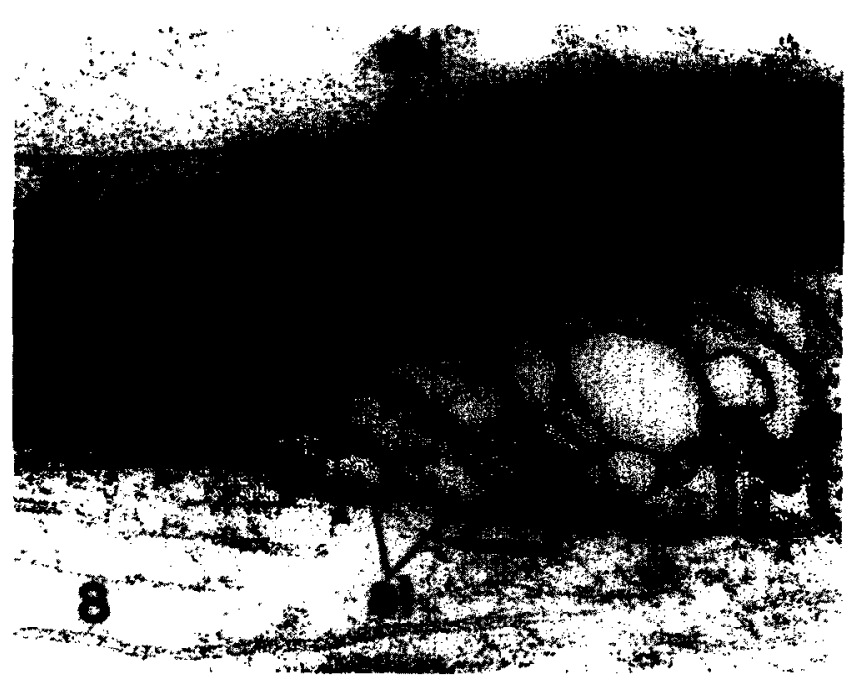

FIGURE 8. Electron micrograph demonstrating extensive axoglial dysjunction, characterized by loss of electron dense junctional complexes (arrowheads) between the paranodal terminal myelin ( $\mathrm{ml}$ ) loops and the axolemma (al). Magnification $\times 70,000$.

due to increased regeneration in response to ARI intervention..$^{20}$ However, the increase in fiber density has been most evident in patients with the highest pretreatment nerve fiber densities. ${ }^{20}$ Therefore, fiber density and its subsequent response to ARI therapy would be particularly subject to selection bias during recruitment. Indeed, the fact that fiber density appeared to be reduced rather than increased in tolrestat-treated versus reference patients could possibly be interpreted as showing that tolrestat accelerated rather than ameliorated fiber loss. By this argument, the increase in \%regenerated would be regarded as a response to increased injury, and the reductions in \%axoglial and $\%$ segmental would be viewed as accelerated loss of previously damaged nerve fibers. However, the absence of any increase in the frequency of endstage nerve fibers damage such as \%Wallerian, and particular sensitivity of regenerating nerve fibers to neurotoxins, makes accelerated nerve-fiber loss in tolrestat-treated patients an unlikely explanation.

The growing recognition that less severely affected patients are more informative in clinical studies of diabetic neuropathy would produce a progressive selection bias tow ard higher fiber densities in more recently initiated trials. Indeed, the tolrestat study represents one of the earliest cohorts of ARI-treated patients, whose recruitment antedated by several years that of the majority of the reference population. Moreover, sural nerve evoked potential amplitudes, which reflect sural nerve fiber density, ${ }^{20}$ were absent in the majority of patients at enrollment in the tolrestat study, whereas all subjects but one had measurable sural amplitudes in the sorbinil biopsy study. ${ }^{20}$ The statistically 

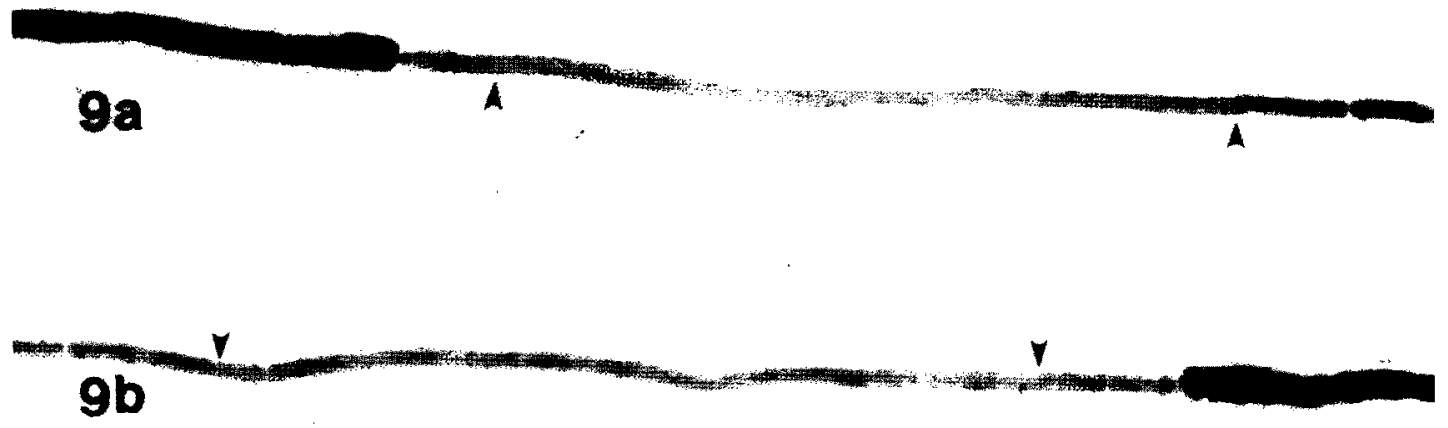

FIGURE 9. Single teased fiber demonstrating segmental demyelination and remyelination by two thinly myelinated internodal segments (arrowheads). Magnification $\times 330$.

significant responses in the grouped morphometric myelin parameters \%demyelinated, \%intercalated, and \%segmental are most consistent with enhancement of remyelination by tolrestat, conceptually an extension of the myelin repair indicated by the reduction in \%axoglial. Thus morphometric evidence suggests both axonal (regeneration) and Schwann cell (remyelination) reparative responses to tolrestat therapy.

In summary, tolrestat effectively penetrates to the site of aldose reductase in human sural nerve in sufficient concentrations to inhibit the glucose-mediated rise in sorbitol and fructose. Morphometric analysis of sural nerve biopsies from patients treated with tolrestat reveals normalization of axoglial dysjunction, segmental demyelination, and increased nerve-fiber regeneration, with the latter increasing in parallel to the duration of tolrestat therapy. These changes are qualitatively similar to those produced by other ARIs in both diabetic humans ${ }^{20,21}$ and rats, ${ }^{22,24}$ and by that analogy, could underlie the reported beneficial effects of tolrestat on nerve conduction in patients. ${ }^{25,26}$

\section{ACKNOWLEDGMENT}

The technical assistance of A. Prashar, University of Manitoba, Winnipeg, Canada, is gratefully acknowledged.

\section{REFERENCES}

1. Johnson PC, Doll SC, Cromey DW: Pathogenesis of diabetic neuropathy. Ann Neurol 19:450-457, 1986.

2. Pirart J: Diabetes mellitus and its degenerative complications: A prospective study of 4,400 patients observed between 1947 and 1973. Diabetes Care 1:168-188, 1978.

3. Dyck PJ, Lais A, Karnes JL, O'Brien P, Rizza R: Fiber loss is primary and multifocal in sural nerves in diabetic polyneuropathy. Ann Neurol 19:425-430, 1986.

4. Sima AAF, Nathaniel V, Bril V, McEwen TAJ, Greene
DA: Histopathological heterogeneity of neuropathy in insulin-dependent and non-insulin-dependent diabetes, and demonstration of axo-glial dysjunction in human diabetic neuropathy. J Clin Invest 81:349-364, 1988.

5. Britland ST, Young RJ, Sharma AK, Clarke BF: Association of painful and painless diabetic polyneuropathy with different patterns of nerve fiber degeneration and regeneration. Diabetes 39:898-908, 1990.

6. Greene DA, Sima AAF, Albers JW, Pfeifer MA: Diabetic neuropathy, in: Rifkin H, Porte D (eds), Ellenberg and Rifkin's Diabetes Mellitus. 4th ed. New York, Elsevier, 1990, pp. 710-755.

7. Dyck PJ, Karnes J, O'Brien PC: Diagnosis, staging, and classification of diabetic neuropathy and associations with other complications, in: Dyck PJ, Thomas PK, Asbury AK, Winegrad AI, Porte DJr (eds), Diabetic Neuropathy. Philadelphia, Saunders, 1987, pp. 36-44.

8. Report and Recommendations of the San Antonio conference on diabetic neuropathy. Diabetes 37:1000-1004, 1988.

9. Young RJ, Macintyre CCA, Martyn CN, Prescott RJ, Ewing DJ, Smith AF, Viberti G, Clarke BF: Progression of subclinical polyneuropathy in young patients with type 1 (insulin-dependent) diabetes: Associations with glycaemic control and microangiopathy (microvascular complications). Diabetologia 29:156-161, 1986.

10. Graf RJ, Halter JB, Pfeifer MA Halar E, Brozovich F, Porte D: Glycemic control and nerve conduction abnormalities in non-insulin-dependent diabetic subjects. Ann Intern Med 94:307-311, 1981.

11. Graf RJ, Halter JB, Halar E, Porte D Jr: Nerve conduction abnormalities in untreated maturity-onset diabetes: Relation to levels of fasting plasma glucose and glycosylated hemoglobin. Ann Intern Med 90:298-303, 1979.

12. Greene DA: Metabolic control, in: Dyck PJ, Thomas PK, Asbury AK, Winegrad AI, Porte D Jr (eds) Diabetic Neuropathy. Philadelphia, Saunders, 1987, pp. 177-187. 
13. Greene DA, Sima AAF, Pfeifer MA, Albers JW: Diabetic neuropathy. Ann Rev Med 41:303-317, 1990.

14. Sima AAF, Nathaniel V, Prashar A, Bril V, Greene DA: Endoneurial microvessels in human diabetic neuropathy: Endothelial cell dysjunction and lack of a treatment effect by aldose reductase inhibitor. Diabetes 40:10901100, 1991.

15. Suzrez G, Rajaram R, Bhuyan KC, Oronsky AL, Goidl JA: Administration of an aldose reductase inhibitor induces a decrease of collagen fluorescence in diabetic rats. J Clin Invest 82:624-627, 1988.

16. Brownlee $M$, Cerami A, Vlassara H: Advanced glycosylation end products in tissue and the biochemical basis of diabetic complications. $N$ Engl J Med 318:13151321, 1988.

17. Greene DA, Lattimer SA, Sima AAF: Sorbitol, phosphoinositides and the sodium-potassium ATPase in the pathogenesis of diabetic complications. $N$ Engl J Med 316:599-606, 1987.

18. Chakrabarti S, Sima AAF, Nakajima T, Yagahasi S, Greene DA: Aldose reductase in the BB rat. Isolation, immunological identification and localisation in the retina and peripheral nerve. Diabetologia 30:244-251, 1987.

19. Peterson MJ, Sarges R, Aldinger CE, MacDonald DP: CP-45, 634: A novel aldose reductase inhibitor that inhibits polyol pathway activity in diabetic and galactosemic rats. Metabolism 23(suppl 1):456-461, 1979.

20. Sima AAF, Bril V, Nathanial V, McEwen TAJ, Brown MB, Lattimer SA, Greene DA: Regeneration and repair of myelinated fibers in sural nerve biopsies from patients with diabetic neuropathy treated with sorbinil, an investigational aldose reductase inhibitor. $N$ Engl J Med 319:548-555, 1988.

21. Sima AAF, Greene DA: Morphologie der peripheren diabetischen Neuropathie und ihre Korrelation mit Funktionstesten. Diabetes und Stoffwechsel 1:29-33, 1992.

22. Sima AAF, Lattimer SA, Yagahasi S, Greene DA: Axoglial dysjunction: a novel structural lesion that accounts for poorly-reversible slowing of nerve conduction in the spontaneously diabetic bio-breeding rat. J Clin Invest 77: 474-484, 1986.

23. Judzewitsch RG, Jaspan JB, Polonsky KS, Weinberg CR, Halter JB, Halar E, Pfeifer MA, Vukadinovic C, Bernstein L, Schneider M, Liang KY, Gabbay KH, Rubenstein $\mathrm{AH}$, Porte $\mathrm{D}$ Jr: Aldose reductase inhibition improves nerve conduction velocity in diabetic patients. N Engl J Med 308:119-125, 1983.

24. Sima AAF, Prashar A, Zhang $W-X$, Chakrabarti S, Greene DA: Preventive effect of long-term aldose re- ductase inhibition (Ponalrestat) on nerve conduction and sural nerve structure in the spontaneously diabetic bio-breeding rat. J Clin Invest 85:1410-1420, 1990.

25. McLeod AF, Boulton AJM, Owens DR, Van Rooy P, Van Gewen JMA, Macrury S, Scarpello JHB, Segers O, Heller SR, Van Der Veen EA, and the North European Tolrestat Study Group. A multi-center trial of the aldose reductase inhibitor tolrestat in patients with symptomatic peripheral neuropathy. Diabete Metab 18:14-20, 1992.

26. Boulton AJM, Levin S, Comstock J: A multicentre trial of the aldose-reductase inhibitor, tolrestat, in patients with symptomatic diabetic neuropathy. Diabetologia 33: 431-437, 1990.

27. Santiago JV, Sönksen PH, Boulton AJM, MacLeod A, Beg M, Bochenek W, Graepel GJ, Gonen B, The Tolrestat Study Group: Withdrawal of ARI Tolrestat in patients with diabetic neuropathy: Effect on nerve function. J Diabet Complications 7:170-178, 1993.

28. Stewart MA, Sherman WR, Kurien MM, Moonsammy GI, Wisgerhof M: Polyol accumulations in nervous tissue of rats with experimental diabetes and galactosemia. I Neurochem 14:1057-1066, 1967.

29. Guerrant GO, Moss CW: Determination of monosaccharides as aldonitrile $\mathrm{O}$-methyloxime, alditol and cyclitol acetate derivatives by gas chromatography. Anal Chem 56:633-638, 1984.

30. Peterson GL: A simplification of the protein method of Lowry et al which is more generally applicable. Anal Biochem 83:345-356, 1977.

31. Van Kampen EI, Zylstra WG: Standardization of hemoglobinometry. The hemoglobincyanide method. Clin Chim Acta 6:538-544, 1961.

32. Hicks DR, Kraml M: Determination of tolrestat, a novel aldose reductase inhibitor, in serum and tissues. Ther Drug Monit 6:328-333, 1984.

33. Sima AAF, Brown MB, Prashar A, Chakrabarti S, Laudadio $C$, Greene DA: The reproducibility and sensitivity of sural nerve morphometry in the assessment of diabetic peripheral polyneuropathy. Diabetologia 35: 560-569, 1992.

34. Sima AAF, Brismar $\mathrm{T}$ : Reversible diabetic nerve dysfunction. Structural correlates to electrophysiological abnormalities. Ann Neurol 18:21-29, 1985.

35. Brismar T, Sima AAF, Greene DA: Reversible and irreversible nodal dysfunction in diabetic neuropathy. Ann Neurol 21:504-507, 1987.

36. Dvornik D: Aldose reductase inhibition. An approach to the prevention of diabetic complications. New York, McGraw Hill, 1987, pp. 222-323. 